\title{
MENGGALI NILAI DAN FUNGSI CERITA RAKYAT SULTAN HADIRIN DAN MASJID WALI AT-TAQWA LORAM KULON KUDUS
}

\author{
Oleh \\ Mohammad Kanzunnudin \\ email moh.kanzunnudin@umk.ac.id
}

Program Studi Pendidikan Bahasa dan Sastra Indonesia

Fakultas Keguruan dan Ilmu Pendidikan Universitas Muria Kudus

\begin{abstract}
Research on people's prose story "Sultan Hadirin and Wali At-Taqwa Loram Kulon Mosque" in Loram Kulon village, Jati sub-district, Kudus district, Central Java; aims to describe the value and function of folklore Sutan Hadirin and Mosque Wali At-Taqwa Loram Kulon. This research uses qualitative approach with ethnography method. Data collection techniques with literature study, observation, in-depth interviews, recording, recording, and shooting. The results show that the people's prose story "Sutan Hadirin and Wali At-Taqwa Loram Kulon Mosque" has the value of local wisdom and educational value. The value of local wisdom in the form of the value of leadership, the value of dedication, the value of tradition, cultural values, and social value. The value of education includes ethics and morals, manners, exemplary and heroism, and religious. The functions include (1) educational means, (2) means to legalize collective social institutions that must be adhered to by members of the community, (3) means to build the character and identity of a society, (4) means for recognition and understanding of values cultural values of a community, and (5) as social capital to interact and communicate between members of a community or community.
\end{abstract}

Keywords: Values, functions, prose stories of the people of Sultan Hadirin and Wali At-Taqwa Mosque Loram Kulon.

\section{Abstrak}

Penelitian tentang cerita prosa rakyat "Sultan Hadirin dan Masjid Wali At-Taqwa Loram Kulon" di desa Loram Kulon, Kecamatan Jati, Kabupaten Kudus, Jawa Tengah; bertujuan untuk mendeskripsikan nilai dan fungsi cerita rakyat Sutan Hadirin dan Masjid Wali At-Taqwa Loram Kulon. Penelitian ini menggunakan pendekatan kualitatif dengan metode etnografi. Teknik pengumpulan data dengan studi pustaka, observasi, wawancara mendalam, perekaman, pencatatan, dan pemotretan. Hasilnya menunjukkan bahwa cerita prosa rakyat "Sutan Hadirin dan Masjid Wali At-Taqwa Loram Kulon" memiliki nilai-nialai kearifan lokal dan nilai pendidikan. Nilai kearifan lokal berupa nilai kepemimpinan, nilai pengabdian, nilai tradisi, nilai budaya, dan nilai sosial. Nilai pendidikan mencakupi etika dan moral, budi pekerti, keteladanan dan kepahlawanan, dan religius. Adapun fungsinya mencakupi (1)sarana pendidikan, (2) sarana untuk mengesahkan pranatapranata sosial bersifat kolektif yang harus ditaati oleh anggota masyarakat, (3) sarana untuk membangun karakter dan identitas suatu masyarakat, (4) Sarana untuk pengenalan dan pemahaman terhadap nilai-nilai budaya suatu masyaraka, dan (5) sebagai modal sosial untuk berinteraksi dan berkomunikasi antaranggota atau komunitas suatu masyarakat.

Kata kunci: Nilai, fungsi, cerita prosa rakyat Sultan Hadirin dan Masjid Wali At-Taqwa Loram Kulon.

\section{PENDAHULUAN}

Kota Kudus merupakan kota terkecil di Propinsi Jawa Tengah (Disparbud Kudus, 2005). Akan tetapi, banyak memiliki cerita rakyat. Salah satu cerita rakyat lisan yang betitel "Sultan Hadirin dan Masjid Wali At-Taqwa Loram Kulon". Cerita lisan "Sultan Hadirin dan
Masjid Loram Kulon" ini merupakan cerita rakyat yang berbentuk cerita prosa rakyat, sangat popular bagi masyarakat Kudus. Cerita lisan ini berkembang di desa Loram Kulon, kecamatan Jati, Kabupaten Kudus, Jawa tengah. Dinyatakan popular, karena hampir sebagian besar masyarakat Kudus mengerti cerita 
tentang Sutan Hadirin dan Masjid Wali At-Taqwa Loram Kulon.

Berdasarkan observasi yang peneliti lakukan, ternyata cerita rakyat berbentuk lisan dengan titel "Sultan Hadirin dan Masjid Wali AtTaqwa Loram Kulon" bagi masyarakat desa Loram Kulon; memiliki makna yang sangat penting dalam konteks awal penyebaran agama Islam di Kudus, nilai tradisi, arsitektur gapura masjid, maupun nilai budaya. Seperti tradisi mengelilingi gapura masjid bagi pasangan pengatin di desa Loram Kulon, sampai sekarang asih dijalan dengan khidmat. Begitu juga tradisi Kirab Ampyang Maulid untuk memperingati Maulid Nabi Muhammad SWA tiap tanggal 12 Robi'ul Awwal, sampai sekarang masih dilaksanakan dengan meriah dan khidmat.

Berdasarkan wawancara dengan Bapak Afron Amaludin (48) Juru Kunci Masjid dan Juru pelindung pengembangan dan pemanfaatan benda cagar budaya gapura Masjid Loram Wali AtTaqwa Loram Kulon, peneliti merekontruksikan cerita prosa rakyat "Sutan Hadirin danMasjid At-Taqwa Loram Kulon". Beranjak dari rekonstruksi cerita tersebut, penulis menemukan nilai-nilai kearifan lokal maupun nilai-nilai pendidikan yang terkandung dalam cerita lisan "Sutan Hadirin dan Masjid At-Taqwa Loram Kulon”. Begitu juga tentang fungsi yang terkandung didalamnya, sangat positif dikembangkan dalam aktivitas kehidupan sehari-hari.

Beranjak pada pertimbangan tersebut, maka peneliti meneliti cerita prosa rakyat "Sutan Hadirin dan Masjid Wali At-Taqwa Loram Kulon" berdasarkan sudut pandang

\section{2 | Jurnal Kredo} Vol. 1 No. 1 Oktober 2017 nilai dan fungsinya. Adapun permasalahan dalam penelitian ini, yakni (1) nilai-nilai apakah yang terkandung dalam cerita rakyat Sutan Hadirin dan Masjid Wali AtTaqwa Loram Kulon, dan (2) fungsi apa saja yang dimiliki oleh cerita rakyat Sutan Hadirin dan Masjid Wali At-Taqwa Loram Kulon. Mengenai tujuan penelitian ini untuk mendeskripsikan nilai dan fungsi cerita rakyat Sutan Hadirin dan Masjid Wali At-Taqwa Loram Kulon.

\section{KAJIAN TEORI Esensi Cerita}

Berbicara cerita rakyat, tidak dapat lepas dari budaya lisan, sebagai budaya tua yang lama berkembang di bumi nusantara. Cerita rakyat sebagai karya sastra bermula dari tradisi lisan yang dihasilkan dan sebarkan oleh neneng moyang bangsa Indonesia. Bahwa cerita rakyat sebagai sastra lisan, sebagaimana diungkapkan oleh Hutomo (1991:1) cerita rakyat termasuk jenis sastra lisan, sedangkan yang dimaksud dengan sastra lisan adalah kesusasteraan yang mencakup ekspresi kesusasteraan warga dan kebudayaan yang disebarkan dari mulut ke mulut. Pendapat bahwa cerita rakyat sastra lisan, juga diungkapkan oleh Rahmanto \& B. Kaswanti Purwo (1999: viii), bahwa cerita rakyat merupakan sastra lisan yang di dalamnya mementingkan aspek mimesis, tidak hanya dibentuk tetapi juga membentuk kebudayaan lisan dengan the oral state of mind yang dapat dikelompokkan kedalam kebudayaan tradisional.

Cerita yang beranjak dari tradisi lisan dan penyebarannya 
melalui mulu ke mulut, juga diungkap Sudjiman (1984:16) bahwa cerita rakyat adalah kisahan anonim yang tidak terikat pada ruang dan waktu, yang beredar secara lisan di tengah masyarakat, termasuk di dalamnya cerita binatang, dongeng, legenda, mitos, dan saga (lihat Kanzunnudin, 2003:18-19).

Berdasarkan sudut pandang budaya bahwa cerita rakyat lahir dari budaya masyarakat yang diwariskan secara lisan, ditandaskan oleh Harvilahti (2003:200) bahwa cerita rakyat adalah cerita dari mulut ke mulut yang merupakan karya tradisional yang lahir dari budaya masyarakat.

Menurut Sims dan Martine Stephens (2005:1) cerita rakyat adalah lagu dan legenda daerah. Cerita rakyat berkaitan langsung dengan manusia dan bagaimana memaknai dunia yang ada di sekitar manusia. Batasan tersebut hanya menyatakan bentuk cerita rakyat berupa lagu dan legenda dan hal ini berkaitan dengan permasalahan manusia dan sekitarnya. Adapun Kartodirdjo (1986:410-419) secara singkat menyatakan bahwa cerita rakyat merupakan konstruk kesadaran masa lampau dan alam pikiran masyarakat pemiliknya yang bersifat universal.

erdasarkan beberapa pendapat tersebut, peneliti menyimpulkan bahwa esensi cerita rakyat cerita rakyat merupakan bagian kebudayaan bersifat kolektif yang diwariskan oleh nenek moyang (leluhur) kepada generasi penerusnya melalui budaya lisan maupun tulis secara turun temurun yang berisi tentang nilai-nilai kehidupan dengan berbagai variasi bentuk seperti prosa (dongeng, mite, legenda), teka teki, tembang, puisi rakyat (pantun, gurindam, syair), bahasa rakyat (logat), puisi , adat istiadat, kepercayaan rakyat, bunyi isyarat untuk komunikasi rakyat (kentongan, genderang), pakaian tradisional, musik rakyat.

\section{Cerita Prosa Rakyat}

Cerita "Sultan Hadirin dan Masjid Wali At-Taqwa Loram Kulon" merupakan cerita rakyat yang berbentuk cerita prosa rakyat yang ada desa Loram Kulon Kabupaten Kudus. Mengenai bentuk cerita rakyat, Danandjaya (1994:21-22) membagi menjadi tiga kelompok besar. Pertama, cerita rakyat lisan sebagai cerita rakyat yang bentuknya murni lisan. Cerita rakyat yang termasuk dalam kelompok ini (a) bahasa rakyat (logat, julukan, pangkat tradisional, dan titel kebangsawanan); (b) ungkapan tradisional, seperti peribahasa, pepatah, dan pemeo; (c) pertanyaan tradisional, seperti teka-teki; (d) puisi rakyat seperti pantun, gurindam, dan syair; (e) cerita prosa rakyat, seperti mite, legenda, dan dongeng; dan (f) nyanyian rakyat.

Kedua, cerita rakyat sebagian lisan adalah yang bentuknya merupakan campuran unsur lisan dan unsur bukan lisan. Misalnya kepercayaan rakyat yang terdiri atas pernyataan yang bersifat lisan ditambah dengan gerak isyarat yang dianggap mempunyai makna gaib, seperti tanda Salib bagi orang Kristen. Bentuk lainnya seperti permainan rakyat, teater rakyat, tari rakyat, adat-istiadat, upacara, dan pesta rakyat.

Ketiga, cerita rakyat bukan lisan adalah cerita rakyat yang bentuknya bukan lisan walaupun cara 
pembuatannya diajarkan secara lisan. Kelompok ini dibedakan menjadi dua subkelompok, yakni yang material dan yang bukan material. Bentuk folklor yang termasuk golongan material seperti arsitektur rakyat (bentuk rumah asli daerah, bentuk lumbung padi, dan sejenisnya), kerajinan tangan rakyat, pakaian dan perhiasan tubuh adat, makanan dan minuman, dan obat-obatan tradisional. Adapun cerita rakyat yang bukan material seperti gerak isyarat tradisional (gesture), bunyi isyarat untuk komunikasi rakyat (kentongan tanda bahaya di Jawa), dan musik rakyat (lihat Cokrowinoto, 1986:505; Kanzunnudin, 2017).

Berdasarkan pemahaman tersebut menandaskan bahwa cerita rakyat "Sultan Hadirin dan Masjid Loram Kulon" merupakan cerita rakyat lisan sebagai cerita rakyat yang bentuknya murni lisan. Cerita rakyat lisan yang berbentuk cerita prosa rakyat.

\section{Nilai}

Nilai merupakan konsep ukuran yang berkaitan dengan masalah baik-buruk, indah-jelek, benar-salah, adil-alim. Nilai merupakan konsep ukuran yang memungkinkan subjek melakukan penilaian atas objek yang dihadapi. Adapun nilai sebagai konsep ukuran yang diyakini seseorang merupakan bagian kebudayaan (Ihsan, 2010:235236). Definisi ini menekankan bahwa nilai merupakan suatu timbangan tentang baik-buruk, indah- jelek, benar-salah, adil-alim yang ukurannya berdasarkan konteks kebudayaan.

Pandangan tentang nilai berkaitan langsung dengan kadar baik-buru, juga diunkapkan oleh Sulaeman (1998:19), bahwa nilai adalah sesuatu yang dipentingkan manusia sebagai subjek, menyangkut segala sesuatu yang baik atau yang buruk sebagai abstraksi, pandangan, tau maksud berbagai pengalaman dengan seleksi perilaku yang ketat.

ilai sebagai ukuran terhadap yang baik dan yang buruk, maka nilai menjadi ukuran bagi masyarakat dalam menjalankan kehidupan sehari-hari. Hal ini dikemukakan Koentjaraningrat (1990:190) bahwa nilai merupakan konsep-konsep yang bernilai tinggi, berharga, dan sangat penting yang hidup di alam pikiran masyarakat dan berfungsi sebagaiedoman yang memberikan arah dan orientasi kepada kehidupan masyarakat yang bersangkutan.

Nilai sebagai suatu sistem yang teramat penting untuk mengetahui mana yang baik dan lebih baik dan mana kurang baik, mana yang benar dan mana yang tidak salah, diungkapkan oleh Salam (2004: 42) bahwa nilai merupakan pengertianpengertian yang dihayati seseorang mengenai apa yang lebih penting atau kurang penting, apa yang lebih baik atau kurang baik, dan apa lebih benar dan kurang benar. Adapun nilai yang hidup dalam kelompok masyarakat menjadi sebuah sistem nilai. Sistem nilai ini dipatuhi atau ditaati oleh setiap anggota masyarakat. Kepatuhan atau ketaatan anggota masyarakat terhadap sistem nilai tersebut tercermin dalam sikap dan perilaku sehari-hari sehingga mereka dapat memisahkan perilaku yang patut atau perilaku yang tidak patut untuk dilakukan.

Mengenai nilai sebagai dasar yang memandu manusia dalam berperilaku ditandaskan Kosasih (2015) bahwa nilai merupakan seperangkat tingkah laku seseorang menyangkut segala sesuatu yang baik 
atau yang buruk sebagai abstraksi atau maksud berbagai pengalaman dengan seleksi perilaku yang ketat, baik yang bersumber pada metafisika, teologi, estetika, maupun logika.

Berdasarkan berbagai batasan nilai tersebut, peneliti menyimpulkan bahwa nilai merupakan konsep bernilai tinggi dan sangat penting yang dipercaya atau diyakini, dihormati, dan dijadikan dasar dalam bertindak bagi individu maupun kelompok masyarakat. Konsep tersebut menjadi tolokukur atau norma baik-buruk, indah-jelek, benar-salah, adil-lalim berdasarkan konteks kebudayaan. Oleh sebab itu, nilai bersifat mengikat bagi seseorang maupun kelompok orang suatu masyarakat dalam berpikir, berucap, dan bertindak bertindak.

\section{Nilai Kearifan Lokal}

Setiap masyarakat memiliki nilai-nilai yang berkaitan langsung perilaku sehar-hari. Nilai-nilai yang dihasilkan pemikiran kolektif oleh anggota masyarakat yang bersangkutan. Nilai-nilai tersebut sudah berjalan sejak lama dan diwariskan dari generasi ke generasi berikutnya. Nailai-nilai inilah yang dikenal dengan nilai kearifan loka. Syarifuddin (2008:102) menyatakan bahwa kearifan lokal merupakan hasil pemikiran kolektif yang diwariskan oleh nenek moyangnya yang kemudian dijaga, dipelihara, ditaati, dan dilaksanakan oleh generasi berikutnya untuk keharmonisan dalam dunianya.

Kistanto

mengungkapkan bahwa nilai kearifan local bersumber pada tradisi budaya yang berisi ajaran, nasihat, anjuran, larangan dan aturan yang telah dijalankan dan diwariskan dari satu generasi kepada generasi lainnnya agar dapat menjadi landasan, pedoman, dan tuntunan sikap, tingkah-laku dan perbuatan individu dan kelompok dalam menjalankan hidup secara harmonis bersama lingkungannya.

Nailai kearifan local sebagai kekayaan budaya lokal yang berisi kebijakan hidup diungkapkan oleh Suyatno (2015), bahwa kearifan lokal merupakan suatu kekayaan budaya lokal yang mengandung kebijakan hidup, pandangan hidup (way of life) yang mengakomodasi kebijakan (wisdom) dan kearifan hidup. Kearifan lokal juga sebagai identitas bangsa yang merupakan warisan masa lalu yang berasal dari leluhur, yang tidak hanya terdapat dalam sastra tradisional (sastra lisan atau sastra tulis) sebagai refleksi masyarakat penuturnya, tetapi terdapat dalam berbagai bidang kehidupan nyata, seperti filosofi dan pandangan hidup, kesehatan, dan arsitektur.

Pengertian kearifan lokal secara terperinci diungkapkan Mundardjito (1986:40), bahwa hakikat kearifan lokal mencakupi hal-hal (1) mampu bertahan terhadap budaya luar, (2) memiliki kemampuan mengakomodasi unsurunsur budaya luar, (3) mempunyai kemampuan mengintegrasi unsurunsur budaya luar ke dalam kebudayaan asli, (4) memiliki kemampuan mengendalikan, dan (5) mampu memberikan arah pada perkembangan budaya.

Kearifan lokal sebagai nilai yang tinggi dan kuat, maka dijadikan rujukan oleh semua anggota masyarakat dalam melaksanakan aktivitas sehari-hari. Sebagaimana dinyatakan oleh Haryono \& Akhmad Sofyan (2013:74-76) bahwa kearifan lokal merupakan bagian budaya 
daerah yang mengandung nilai-nilai yang mencerminkan budi pekerti yang dapat digunakan sebagai acuan untuk menumbuhkembangkan situasi bermasyarakat yang penuh dengan kerukunan dan kedamaian. Nilainilai kearifan lokal dapat dijadikan perekat dan acuan dalam hidup berbangsa dan bernegara.

Beranjak pendapat para pakar tersebut, peneliti menyimpulkan bahwa nilai kearifan lokal adalah pemikiran, pandangan, kepercayaan (idiologi), sikap, dan tindakan yang berakar pada nilai-nilai budaya lokal (setempat). Nilai-nilai kearifan lokal ini merupakan hasil pemikiran kolektif suatu masyarakat yang bernilai positif dan luhur yang telah teruji oleh perjalanan waktu sehingga mengkristal menjadi tradisi, norma, etika, adan nilai yang dipercaya dan diaktualisasikan dalam perilaku oleh masyarakat pemiliknya.

Mengenai cakupan nilai-nilai kearifan lokal yakni nilai kepemimpinan, nilai pengabdian, nilai tradisi, nilai kebudayaan, dan nilai sosial.

\section{Nilai Pendidikan}

Pendidikan dapat diartikan sebagai latihan mental, moral, dan fisik yang melahirkan manusia berbudaya tinggi untuk melaksanakan tugas kewajiban dan tanggung jawab dalam masyarakat selaku hamba Allah. Dalam hal ini pendidikan berarti menumbuhkan personalitas (kepribadian) serta menanamkan tanggung jawab (Ainusysyam (2009:38). Adapun Sugihartono at.al. (2007:3-4) menyatakan bahwa pendidikan adalah suatu usaha yang dilakukan secara sadar dan sengaja untuk mengubah tingkah laku manusia baik secara individu maupun kelompok untuk mendewasakan manusia melalui upaya pengajaran dan pelatihan.

Pendidikan sebagai proses perubahan tingkah laku diungkapkan Partowisastro (1983:9), bahwa pendidikan merupakan suatu proses, suatu aktivitas dan suatu rangsang yang diarahkan kepada memprodusir perubahan-perubahan tingkah laku dari seseorang yang diinginkan sesuai dengan tujuan-tujuan pendidikan. Pemahaman tingkah laku tidak hanya terbatas pada aksi, tiap respon atau apa saja yang diokerjakan oleh seseorang; tetapi juga apa yang dipikirkan, pandangan-pandangannya serta sikap-sikapnya terhadap beberapa soal tertentu.

Mengenai pendidikan sebagai proses mentransfer nilai dinyatakan Panjaitan (2014:57) bahwa pendidikan merupakan media untuk mentransfer nilai-nilai kebudayaan kepada generasi penerus. Terutama nilai-nilai kebudayaan yang berkaitan dengan tradisi atau adatistiadat yang dapat mewujudkan kesejahteraan hidup. Dengan penanaman nilai-nilai kebudayaan dapat memajukan berbagai dimensi kehidupan, termasuk nilai-nilai pendidikan.

Berdasarkan urain tersebut, peneliti menyimpulkan batasan pendidikan adalah suatu upaya terencana untuk mentransformasikan, menanamkan, dan membentuk manusia yang memiliki nilai budipekerti dan etos kerja, cipta (pengetahuan), rasa (afektif), karsa (psikomortorik), keterampilan hidup sehingga mereka menjadi manusia yang merdeka. Manusia yang tidak selalu berada dalam domain ketergantungan kepada orang lain. Manusia yang bermartabat yang 
memiliki kemampuan membedakan mana yang positif dan negatif, dan mampu beradaptasi dengan lingkungan, diri sendiri, dan kepada Tuhannya.

Adapun hal-hal yang tercakup dalam nilai-nilai pendidikan yakni nilai etika dan moral, nilai budi pekerti, nilai keteladanan dan kepahlawanan, dan nilai religius.

\section{Fungsi}

Sebagaimana dinyatakan oleh Danandjaja (1994: 27) bahwa fungsi folkor yakni (1) sebagai alat pengesahan pranata-pranata dan lembaga-lembaga kebudayaan; (2) sebagai alat pemaksa dan pengawas agar norma-norma masyarakat akan selalu dipatuhi anggota kolektifnya; (3) sebagai alat pendidikan anak atau pedagogical device; dan (4) sebagai sistem proyeksi atau projective system, yakni sebagai alat pencermin angan-angan kolektif (lihat Cokrowinoto, 1986: 505).

Manik

(2014:27)

mengungkapkan fungsi cerita rakyat yakni (1) sebagai wahana untuk memahami gagasan pewarisan tata nilai yang tumbuh di masyarakat, (2) sebagai sarana komunikasi antara pencipta dan masyarakat, dan (3) sebagai sarana untuk membangun suasana kolektif dalam membentuk kekuatan positif dan ikatan batin dalam masyarakat.

Fungsi cerita rakyat berkaitan dengan keteladanan, hiburan, dan pendidikan, diungkapkan Mawadah (2013:57), bahwa cerita rakyat memiliki fungsi (1) sebagai hiburan, (2) sebagai suri tauladan karena mengandung pesan-pesan pendidikan moral, dan (3) sebagai media pendidikan bagi siswa.
Fungsi cerita rakyat menurut Kusmayati dan Suminto A. Sayuti (2014) yang bertumpu pada hasil penelitiannya tentang sastra lisan "Mamaca" Pamekasan Madura, yakni (1) mendorong masyarakat menuju tahapan atau tingkatan yang lebih baik, (2) bagi penonton (pembaca) dapat memperoleh inspirasi berkaitan dengan semangat hidup, optimisme, pencerahan, dan kebahagiaan, dan (3) masyarakat dapat memahami nilai-nilai yang bersifat filosofis dan transendental berkaitan dengan kehidupan seharihari. Adapun Amir (2013: 34-42) menyatakan bahwa cerita rakyat memiliki fungsi (1) sosial, (2) menyimpan puitika kosakata yang kaya estetis dan kaya nilai budaya, (3) sarana pendidikan yakni untuk menyampaikan atau mensosialisasi nilai-nilai, (4) ajang nostalgia, (5) mengumpulkan orang atau masyarakat untuk penggalangan dana, dan (6) mengumpulkan orang atau masyarakat untuk mendengarkan pesan-pesan politik.

Menurut

Kartodirdjo (1986:411-416) cerita rakyat memiliki fungsi (1) sebagai karakter dan identitas masyarakat serta sebagai lambang identitas suatu daerah; dan (2) bagi rakyat kecil, cerita rakyat sebagai sarana untuk mengungkapkan realitas yang sepenuhnya mereka percayai.

Pendapat yang hampir senada dengan pernyataan Kartodirdjo mengenai fungsi cerita rakyat, tetapi lebih diperluas, diungkapkan oleh Purwadi (2012: 2-7) bahwa cerita rakyat mempunyai fungsi (1) pembentuk solidaritas sosial; (2) sebagai identitas lokal yang sekaligus merupakan kebanggan kolektif yang berperan sebagai wahana untuk 
melaksanakan refleksi spiritual; (3) sebagai watak atau corak kebudayaan daerah; (4) sebagai sumber informasi tentang kebudayaan daerah; dan (5) sebagai pengokoh atau penguat jatidiri dan kepribadian nasional.

Gazali (2016) yang berpijak pada hasil penelitiannya tentang "Struktur, Fungsi, dan Nilai Nyanyian Rakyat Kaili" menyatakan bahwa fungsi cerita rakyat mencakupi empat dimensi. Pertama, fungsi ritual, yakni suatu bentuk upacara atau perayaan yang berkaitan dengan beberapa kepercayaan atau agama. Kedua, fungsi sosial, yakni mengungkapkan kondisi daqn situasil sosial-kultural, identitas, dan harapan masyarakat pemilik cerita rakyat. Ketiga, fungsi pendidikan, yakni cerita rakyat memuat nilai-nilai luhur yang berfungsi untuk mendidik, seperti nilai estetika, filsafat, etika, dan religi. Keempat, fungsi komunikasi, yakni cerita rakyat menyampaikan berbagai pesan yang dituturkan kepada masyarakat. Pesan yang dituturkan itu mencakupi kejujuran, tanggung jawab, keadilan, koreksi diri, motivasi, dan interaksi sosial.

\section{Rampan}

(2014:13-14)

mengungkapkan bahwa fungsi cerita rakyat yakni (1) sebagai pelipur lara; (2) sebagai sarana pendidikan; (3) kritik sosial atau protes sosial; dan (4) sebagai sarana untuk menyampaikan maksud-maksud yang terpendam.

Janthaluck, Maneerat \& Walailak Qunjit (2012) mengukapkan bahwa fungsi cerita rakyat mencakupi (1) membantu menciptakan ruang komunitas bagi orang-orang di masyarakat; (2) melalui cerita rakyat dapat mengubah

\footnotetext{
8 | Jurnal Kredo Vol. 1 No. 1 Oktober 2017
}

cara berpikir anak-anak dan remaja ke arah pemahaman yang positif terhadap sejarah masyarakatnya; (3) melalui cerita rakyat dapat membangkitkan kembali mengenai kenangan-kenengan tentang tradisi dan ritual; (4) dapat mempererat hubungan orang tua dengan dunia anak-anak; (5) sebagai modal sosial untuk berinteraksi dan berkomunikasi dalam kehidupan bermasyarakat; (6) sarana untuk mengenali dan mengakui nilai budaya asli pemiliki cerita rakyat; dan (7) sebagai identitas bagi masyarakat pemiliki cerita rakyat.

Cerita rakyat juga mempunyai fungsi (1) untuk mengetahui dan memahami perilaku lisan dan sosial masyarakat, (2) sebagai sarana atau media komunikasi antaranggota masyarakat, dan (3) untuk mengetahui dan memahami budaya materiil masyarakat (Bronner 2012). Juga memiliki fungsi sebagai media komunikasi kultural antara orang tua dan anak muda, antarpemuda dan pemudi, antaranggota masyarakat; (2) media komunikasi kultural antarkampung; dan (3) dapat dijadikan ruang komunikasi kultural bagi pemerintah dalam menyampaikan program-programnya kepada masyarakat; dan (4) sebagai media hiburan bagi masyarakat (Udu 2015:65).

Berdasarkan pendapat berbagai pakar tersebut, peneliti menyimpulkan bahwa cerita rakyat memiliki fungsi (1) sarana pendidikan, (2) sarana untuk mengesahkan pranata-pranata sosial bersifat kolektif yang harus ditaati oleh setiap anggota masyarakat, (3) sarana untuk menyebarluaskan nilainilai kebaikan dan keagamaan, (4) sarana untuk kritik atau protes sosial, 
(5) sarana untuk pembentuk karakter dan identitas suatu masyarakat, (6) sarana pengenalan dan pemahaman terhadap nilai-nilai budaya suatu masyarakat; (7) sebagai modal sosial untuk berinteraksi dan berkomunikasi antaranggota suatu masyarakat; dan (8) sarana untuk menghibur.

\section{METODE PENELITIAN}

Dalam penelitian cerita prosa rakyat "Sultan Hadirin dan Masjid Wali At-Taqwa Loram Kulon Kudus" menggunakan pendekatan kualitatif dengan metode etnografi. Penelitian kualitatif menurut Moleong (2001: 3-6) sebagai prosedur penelitian yang menghasilkan data deskriptif berupa kata-kata tertulis atau lisan dari orang-orang dan perilaku yang diamati, data yang dikumpulkan berupa kata-kata, gambar, dan bukan angka-angka. Adapun laporan penelitian berisi kutipan-kutipan

Data untuk memberi gambaran penyajian laporan. Mengenai datadata tersebut mungkin berasal dari naskah wawancara, catatan-catatan lapangan, foto, videotape, dokumen pribadi, catatan atau memo, dan dokumen resmi lainnya (lihat Satori dan Aan Komariah,2014:28; Miles dan A. Michael Huberman, 2007: 15; dan Hendrarso 2013:166).

Metode etnografi sebagai desain kualitatif yang penelitiannya mendeskripsikan, menafsirkan, dan untuk mengeksplorasi kelompok kebudayaan yang mencakupi nilai, perilaku, keyakinan, dan bahasa (Creswell,2015:131). Metode etnografi ini berfokus pada pemahaman sistem makna budaya
(Spradley, 2007:10). Penelitian ini bersifat idiographik, yakni mendeskripsikan budaya dan tradisi yang ada (Muhadjir,2002:319).

\section{Teknik Pengumpulan Data}

Teknik pengumpulan data dilakukan dengan cara studi pustaka, observasi, wawancara mendalam, perekaman, pencatatan, dan pemotretan.

\section{HASIL DAN PEMBAHASAN}

\section{Nilai Cerita Prosa Rakyat Sultan Hadirin dan Masjid Wali At- Taqwa Loram Kulon}

Sebagaimana dijelaskan bahwa nilai kearifan lokal adalah pemikiran, pandangan, kepercayaan (idiologi), sikap, dan tindakan yang berakar pada nilai-nilai budaya lokal (setempat). Nilai-nilai kearifan lokal ini merupakan hasil pemikiran kolektif suatu masyarakat yang bernilai positif dan luhur yang telah teruji oleh perjalanan waktu sehingga mengkristal menjadi tradisi, norma, etika, adan nilai yang dipercaya dan diaktualisasikan dalam perilaku oleh masyarakat pemiliknya.

Batasan tentang nilai tersebut yang menjadi pijakan peneliti dalam meneliti cerita prosa rakyat "Sultan Hadirin dan Masjid Wali At-Taqwa Loram Kulon Kudus". Adapun berdasarkan analisis, cerita prosa rakyat "Sultan Hadirin dan Masjid At-Taqwa Loram Kulon Kudus" memiliki nilai kearifan lokal dan nilai pendidikan.

Nilai kearifan lokal merupakan pemikiran, pandangan, kepercayaan (idiologi), sikap, dan tindakan yang berakar pada nilai-nilai budaya lokal (setempat). Nilai-nilai kearifan lokal 
ini merupakan hasil pemikiran kolektif suatu masyarakat yang bernilai positif dan luhur yang telah teruji oleh perjalanan waktu sehingga mengkristal menjadi tradisi, norma, etika, adan nilai yang dipercaya dan diaktualisasikan dalam perilaku oleh masyarakat pemiliknya. Adapun cakupan nilai-nilai kearifan lokal yakni nilai kepemimpinan, nilai pengabdian, nilai tradisi, nilai kebudayaan, dan nilai sosial.

Mengenai

pendidikan

merupakan suatu upaya terencana untuk mentransformasikan, menanamkan, dan membentuk manusia yang memiliki nilai budipekerti dan etos kerja, cipta (pengetahuan), rasa (afektif), karsa (psikomortorik), keterampilan hidup sehingga mereka menjadi manusia yang merdeka. Manusia yang tidak selalu berada dalam domain ketergantungan kepada orang lain. Manusia yang bermartabat yang memiliki kemampuan membedakan mana yang positif dan negatif, dan mampu beradaptasi dengan lingkungan, diri sendiri, dan kepada Tuhannya. Adapun hal-hal yang tercakup dalam nilai-nilai pendidikan yakni nilai etika dan moral, nilai budi pekerti, nilai keteladanan dan kepahlawanan, dan nilai religius.

\section{Nilai Kearifan Lokal}

Cerita prosa rakyat "Sultan Hadirin dan Masjid Wali At-Taqwa Loram Kulon" memiliki nilai-nilai kearifan lokal yang mencakupi nilai kepemimpinan, nilai pengabdian, nilai tradisi, nilai budaya, dan nilai sosial.

Nilai kepemimpinan diungkapkan melalui sikap Sultan Hadirin yang bijaksana dalam menyebarluaskan agama Islam tanpa menyakiti masyarakat atau orang

10 | Jurnal Kredo Vol. 1 No. 1 Oktober 2017 yang masih banyak memeluk agama Hindu-Budha. Sultan Hadirin menyebarluaskan nilai-nilai agama Islam dengan santun, pola-pola seni budaya hingga membangun gapura masjid yang memiliki kemiripan bentuk dengan bangunan candi. Hal itu ternyata menjadi daya tarik bagi masyarakat untuk datang ke masjid dan belajar agama Islam kepada Sultan Hadirin.

Nilai kepemimpinan juga dilukiskan melalui sikap bijaksana Sultan Hadirin ketika ada seseorang yang bertanya cara bersedekah. Kemudian Sultan Hadirin menjelaskan bahwa seseorang dalam bersedekah harus disesuaikan dengan kemampuannya dan disesuaikan dengan keadaan lingkungan masyarakat yang bersedekah. Lebih lanjut Sultan Hadirin memerintahkan kepada orang yang tanya tadi untuk melakukan sedekah dalam bentuk Nasi Kepel Tujuh Bungkus dengan lauknya Bothok juga Tujuh Bungkus.

Seseorang tersebut, meminta penjelasan kembali kepada Sultan Hadirin, tentang sedekah yang serba "Tujuh". Kemudian Sultan Hadirin menjelaskan bahwa kata "Tujuh" memiliki makna yang berkaitan dengan perjalanan kehidupan seseorang. Kata "tujuh" memiliki makna pitulung (pertolongan), pitutur (nasihat), dan pitudhuh (petunjuk). Orang hidup harus mendapatkan ketiga hal itu dalam menjalani hidupnya sehingga selamat dunia akherat.

Petuah-petuah tersebut akhirnya dilaksanakan oleh seluruh masyarakat Loram Kulon. Masyarakat Loram Kulon dalam bersedekah melaksanakan amanah 
yang telah dijelaskan oleh Sultan Hadirin.

Cara, sikap, dan penjelasanpenjelasan yang bersifat petuah tersebut menunjukkan bahwa Sultan Hadirin memiliki nilai kepemimpinan yang santun, bijak, dan selalu menanamkan nilai-nilai kebaikan dan kebenaran dalam menjalakan hidup bagi masyarakat.

Mengenai nilai pengabdian, ditunjukkan oleh prinsip dan sikap hidup Sultan Hadirin yang diperuntukkan untuk menyebarluaskan nilai-nilai kebaikan dan keagamaan. Seluruh hidupnya diabdikan untuk melayani masyarakat.

Mengenai nilai tradisi, diungkapkan melalui kebiasaan masyarakat Loram Kulon melakukan sedekah nasi kepel tujuh bungkus dan bothok tujuh bungkus serta Ampyang Maulid. Begitu juga tradisi mengelilingi Gapura Masjid AtTaqwa Loram Kulon. Setiap ada warga masyarakat Desa Loram Kulon menikah, maka Sultan Hadirin yang menikahkan dan sekaligus mendoakan. Ketika Sultan Hadirin mendoakan pasangan penganten, maka pasangan penganten yang bersangkutan berjalan mengelilingi gapura masjid. Begitu juga kebiasaan melaksanakan tradisi Ampyang Maulid yang tetap dilaksanakan oleh masyarakat Lorm Kulon Kudus.

Nilai budaya diungkapkan melalui seni arsitektur atau bangunan gapura masjid. Gapura Masjid Wali At-Taqwa arsitekturnya tidak sebagaiaman gaupra masjid padam umunya. Seni bangunannya menyerupai bangunan sebuah candi sehingga memiliki daya tarik bagi masyarakat setempat maupun masyarakat di luar desa Loram Kulon.

Nilai budaya juga diungkapkan melalui kirab Ampyang Maulud. Kirab Ampyang Maulud yang melibatkan seluruh masyarakat desa Loram Kulon untuk melakukan kirab (arak-arakan). Kirab ini dilaksanakan tiap 12 Robiul Awal. Kirab ini untuk memperingati lahirnya Nabi Muhammad SWA. Bahkan sekarang kirab Ampyang Maulid menjadi simbol perayaan peringatan Maulid Nabi Muhammad SAW. Kirab tersebut merupakan peristiwa seni budaya yang sangat menarik bagi masyarakat desa Loram Kulon maupun masyarakat di luar desa Loram Kulon.

\section{Nilai Pendidikan}

Cerita prosa rakyat "Sultan Hadirin dan Masjid Wali At-Taqwa Loram Kulon" memiliki nilai pendidikan berupa etika dan moral, budi pekerti, keteladanan dan kepahlawanan, dan religius.

Nilai Pendidikan yang berupa etika dan moral diungkapkan melalui sikap Sultan Hadirin yang membangun gapura masjid menyurupai gaya bangunan candi. Candi sebagai simbol agama HinduBudha. Hal ini dimaksudkan agar tidak terjadi benturan nilai antara agama Islam yang disebarkan dengan agama masyarakat Loram Kulon yang ketika itu masih banyak menganu agama Hindu-Budha. Sultan Hadirin mempertimbangkan nilia-nilai baik-buruknya, karena pada waktu itu masih banyak masyarakat yang menganut agama Hindu-Budha. Adapun pada sisi lain untuk menarik masyarakat agar mau 
berkunjung ke masjid, kemudian diperkenalkan dengan nilai-nilai agama Islam.

Nilai budi pekerti ditunjukkan oleh kepribadian Sultan Hadirin yang baik. Ketika ia ditawari untuk menggantikan kedudukan ayahnya sebagai Sultan di Aceh, ia tidak bersedia. Hal ini disebabkan adik kandung bernama Sultan Taqyin tidak setuju. Bahkan Sultan Taqyin memprotes jika yang menggantikan kedudukan ayahnya, kakaknya, yakni Sultan Hadirin yang ketika itu masih bernama Sultan Toyib. Sultan Taqyin merasa berhak juga untuk menggantikan ayahnya. Akhirnya Sultan Hadirin tidak bersedia untuk menggantikan kedudukan ayahnya sebagai Sultan di Aceh. Ia menyerahkan kepada adiknya. Kemudian ia mengembara sampai ke negeri Cina untuk menuntut ilmu agama maupun ilmu pengetahuan yang lain.

Nilai keteladanan dan kepahlawanan diungkapkan melalui sikap Sultan Hadirin, yakni sikap menunjukkan nilai-nilai keteladanan yang sangat baik, yakni (1) dalam menyebarkan agama dengan cara dan sikap yang sangat simpatik (baik) dan tidak menyakit masyarakat; (2) Sultan Hadirin mengajarkan kepada masyarakat untuk bersedekah sesuai dengan kemampuannya; (3) Sultan Hadirin juga mampu memfungsikan masjid untuk keperluan atau kepentingan masyarakat, yakni untuk menikahkan para pengantin; dan (4) Sultan Hadirin menggerakkan masyarakat untuk memperingati Maulid Nabi Muhammad SWA dengan kirab Ampyang Maulid.

Nilai religius diungkapkan diungkapkan melalui dedikasi Sultan Hadirin dalam hal (1) mengabdikan diri untuk menyiarkan agama Islam; (2) Sultan Hadirin mengajari masyarakat untuk bersedekah; (3) Sultan Hadirin membangun masjid sebagai tempat beribadah, menyebarluaskan nilai-nilai agama Islam, dan menikahkan pengantin secara Islam; dan (4) eelalu menanamkan nilai-nilai Islam dalam tindakannya, seperti ketika masyarakat disuruh bersedekah dengan nasi kepel tujuh bungkus dengan lauk bothok tujuh bungkus, memiliki maksud bahwa angka tujuh (pitu) bermakna "pitulung" : pertolongan, "pitutur" : nasihat, dan "pituduh": petunjuk. Setiap orang harus mendapatkan tiga hal tersebut dalam menjalani hidup di dunia.

Berdasarkan uraian mengenai nilai-nilai kearifan lokal dan nilainilai pendidikan yang dikandung cerita prosa rakyat "Sultan Hadirin dan Masjid Wali At-Taqwa Loram Kulon" , maka dapat diabstrasikan dalam tabel sebagai berikut ini.

Tabel 1. Nilai Kearifan Lokal dan Nilai Pendidikan dalam Cerita Prosa Rakyat Sultan Hadirin dan Masjid Wali At-Taqwa Loram Kulon

\begin{tabular}{|l|l|}
\hline \multicolumn{1}{|c|}{ Nilai } & \multicolumn{1}{c|}{ Bentuk } \\
\hline $\begin{array}{l}\text { Kearifan } \\
\text { Lokal }\end{array}$ & $\begin{array}{l}\text { Nilai kepemimpinan } \\
\text { Nilai pengabdian } \\
\text { Nilai tradisi }\end{array}$ \\
\hline
\end{tabular}

12 | Jurnal Kredo Vol. 1 No. 1 Oktober 2017 


\begin{tabular}{|c|c|}
\hline & $\begin{array}{l}\text { Nilai budaya } \\
\text { Nilai sosial }\end{array}$ \\
\hline Pendidikan & $\begin{array}{l}\text { 1. Nilai etika dan moral } \\
\text { 2. Nilai budi pekerti } \\
\text { 3. Nilai keteladanan dan kepahlawanan } \\
\text { 4. Nilai religius. }\end{array}$ \\
\hline
\end{tabular}

\section{Fungsi Cerita Prosa Rakyat Sultan Hadirin dan Masjid Wali At- Taqwa Loram Kulon}

Cerita prosa rakyat "Sultan Hadirin dan Masjid Wali At-Taqwa Loram Kulon" memiliki fungsi sebagai (1) sarana pendidikan, (2) sarana untuk mengesahkan pranatapranata sosial bersifat kolektif yang harus ditaati oleh anggota masyarakat, (3) sarana untuk membangun karakter dan identitas suatu masyarakat, (4) Sarana untuk pengenalan dan pemahaman terhadap nilai-nilai budaya suatu masyaraka, dan (5) sebagai modal sosial untuk berinteraksi dan berkomunikasi antaranggota suatu masyarakat. $\begin{array}{lrr}\text { Fungsi } & \text { sebagai } & \text { sarana } \\ \text { pendidikan ditunjukkan } & \text { melalui } \\ \text { tokoh Sultan Hadirin yang }\end{array}$ mentransformasikan nilai-nilai etika dan moral, pekerti, keteladanan dan kepahlawanan, dan religius kepada masyarakat Loram Kulon dan sekitarnya. Adapun sebagai sarana untuk mengesahkan pranata-pranata sosial bersifat kolektif yang harus ditaati oleh anggota masyarakat, ditunjukkan (a) pranata perkawainan (pengatin) yang telah dinikahkan di Masjid Wali At-Taqwa Loram Kulon, sepasang pengantin yang bersangkutan mengelilingi gapura masjid; (b) diadakan sedekah nasi kepel tujuh bungkus dengan lauk bothok tujuh bungkus; dan (c) tradisi
Ampyang Maulid yang dilaksanakan setiap 12 Robi'ul Awal hingga sekarang menjadi simbol peringatan Maulid Nabi Muhammad SAW.

Fungsi sebagai sarana untuk membangun karakter dan identitas suatu masyarakat, ditunjukkan oleh sikap Sultan Hadirin yang bijaksana, religius, dan sosial (memperhatikan orang lain atau masyarakat) dengan sedekah. Hal ini menunjukkan bahwa seseorang atau suatu kelompok masyarakat harus memiliki sikap (pribadi) yang kuat yang didasari sikap bijak, religius, sosial. Karakter Sultan Hadirin yang kuat dalam menyebarluaskan nilai-nilai kebaikan dan keagamaan menjadi panutan atau teladan bagi masyarakat Loram Kulon dan sekitarnya.

Mengenai fungsi sebagai sarana untuk pengenalan dan pemahaman terhadap nilai-nilai budaya suatu masyarakat, ditunjukkan adanya tradisi mengelilingi gapura masjid. Juga adanya tradisi Ampyang Maulid untuk memperingati Maulid Nabi Muhammad SAW setiap 12 Robi'ul Awal. Begitu juga adanya sedekah nasi kepel tujuh bungkus dengan lauk bothok tujuh bungkus. Hal mengajarkan kepada masyarakat terhadap penanaman nilai-nilai budaya yang harus dimiliki oleh masyarakat yang bersangkutan. 
Adapun tentang fungsi sebagai modal sosial untuk berinteraksi dan berkomunikasi antaranggota suatu masyarakat, ditunjukkan dengan adanya amanah Sultan Hadirin kepada masyarakat untuk melakukan sedekah dengan nasi kepel tujuh bungkus dengan lauk bothok tujuh bungkus dan Ampyang Maulid. Kegiatan tersebut dapat mempertemukan antaraseseorang maupun antarkelompok masyarakat untuk saling berinteraksi dan berkomunikasi sehingga melahirkan nilai-nilai sosial dan aspek-aspek sosial bagi masyarakat yang bersangkutan.

\section{PENUTUP}

Berdasarkan hasil dan pembahasan tentang nilai dan fungsi cerita prosa rakyat "Sultan Hadirin dan Masjid Wali At-Taqwa Loram Kulon" dapat disimpulan hal-hal berikut ini.

Pertama, cerita prosa rakyat "Sultan Hadirin dan Masjid Wali AtTaqwa Loram Kulon" memiliki nilai kearifan lokal berupa nilai kepemimpinan, nilai pengabdian, nilai tradisi, nilai budaya, dan nilai sosial.

Kedua, cerita prosa rakyat "Sultan Hadirin dan Masjid Wali AtTaqwa Loram Kulon" mempunyai nilai pendidikan berupa nilai etika dan moral, nilai budi pekerti, nilai keteladanan dan kepahlawanan, dan nilai religius.

Ketiga, fungsi yang dikandung cerita prosa rakyat "Sultan Hadirin dan Masjid Wali At-Taqwa Loram Kulon" mencakupi fungsi sebagai (1) sarana pendidikan, (2) sarana untuk mengesahkan pranata-pranata sosial

14 | Jurnal Kredo Vol. 1 No. 1 Oktober 2017 bersifat kolektif yang harus ditaati oleh anggota masyarakat, (3) sarana untuk membangun karakter dan identitas suatu masyarakat, (4) Sarana untuk pengenalan dan pemahaman terhadap nilai-nilai budaya suatu masyaraka, dan (5) sebagai modal sosial untuk berinteraksi dan berkomunikasi antaranggota suatu masyarakat. 


\section{DAFTAR PUSTAKA}

Ainusysyam, Fadlil Yani. 2009. "Pendidikan Akhlak" dalam Mohammad Ali (Eds.) Ilmu dan Aplikasi Pendidikan Bagian III: Pendidikan Disiplin Ilmu. Bandung: Imperal Bhakti Utama.

Amir, Adriyetti. 2013. Sastra Lisan Indonesia. Yogyakarta: ANDI.

Bronner, Simon J. 2012. "Practice Theory in Folklore and Folklife Studies". Folklore 123 (April 2012): 23-47. http://dx.doi.org/10.1080/0015587X2012.642985.

Cokrowinoto, Sardanto. 1986. "Manfaat Folklor bagi Pembangunan Masyarakat" dalam Soedarsono (Ed.) Kesenian, Bahasa dan Folklor Jawa. Yogyakarta: Proyek Penelitian dan Pengkajian Kebudayaan Nusantara (Javanologi) Direktorat Jenderal Kebudayaan Departemen Pendidikan dan Kebudayaan.

Creswell, John W. 2015. Penelitian Kualitatif \& desain Riset: Memilih di antara Lima Pendekatan. Terjemahan Ahmad Lintang Lazuardi. Yogyakarta: Pustaka Pelajar.

Danandjaja, James. 1994. Folklor Indonesia: Ilmu Gosip, Dongeng, dan lain-lain. Jakarta: Grafiti.

Dinas Pariwisata dan Kebudayaan Kabupaten Kudus. 2005. Peninggalan Sejarah dan Purbakala Kabupaten Kudus. Kudus: Disparbud Kudus

Haryono, Akhmad \& Akhmad Sofyan. 2013. "Pemahaman Terhadap Kearifan Lokal Madura: Sebagai Antisipasi Era Globalisasi \& Informasi Menuju Tercapainya Keharmonisan Hidup Antaretnis dalam Perspektif Bahasa dan Budaya" dalam Novi Anoegrajekti \& Sudartomo Macaryus (Eds.) Prosiding Seminar Nasional Identitas dan Kearifan Masyarakat Dalam Bahasa dan Sastra. Yogyakarta: Jurusan Sastra Indonesia Fakultas Sastra Universitas Jember dan Kepel Press.

Hendrarso, Emy Susanti. 2013. "Penelitian Kualitatif: Sebuah Pengantar" dalam Bagong Suyanto dan Sutinah (Eds.) Metode Penelitian Sosial: Berbagai Alternatif Pendekatan. Jakarta: Kencana Prenadamedia.

Hutomo, Suripan Sadi. 1991. Mutiara Yang Terlupakan: Pengantar Studi Sastra Lisan. Surabaya: HISKI.

Ihsan, H.A. Fuad. 2010. Filsafat Ilmu. Jakarta: Rineka Cipta.

Janthaluck, Maneerat dan Wilailak Qunjit. 2012. "Folklore, Restoration of Social Capital and Community Culture". Procedia Social and Behavioral Sciences. 65. Hlm. 218-224.

Kanzunnudin, Mohammad. 2003. Kamus Istilah Drama. Rembang: Yayasan Adhigama.

Kanzunnudin, Mohammad. 2017. Peran Cerita Prosa Rakyat dalam Pendidikan Karakter Siswa. Makalah disampaikan dalam seminar nasional Pembelajaran Bahasa dan Sastra Indonesia Berbasis Kearifan Lokal dalam Pembentukan Karakter Bangsa yang diselenggarakan Program Pendidikan Bahasa dan Sastra Indonesia FKIP UMK dan Balai Bahasa Jawa Tengah, di Universitas Muria Kudus, Kamis, 18 Mei. 
Kistanto, Nurdien H. 2012. Pencapaian Profesionalisme Guru melalui Pendidikan Karakter Berbasis Kearifan Lokal. Makalah disajikan dalam Seminar Nasional Universitas Muria Kudus, Kudus, 10 Juli.

Koentjaraningrat. 1990. Pengantar Ilmu Antropologi. Jakarta: Rineka Cipta.

Kartodirdjo, A. Sartono. 1986. "Suatu Tinjauan Fenomenologi tentang Folklore Jawa” dalam Soedarsono (Ed.). Kesenian, Bahasa dan Folklor Jawa. Yogyakarta: Departemen Pendidikan dan Kebudayaan.

Kosasih, H. Aceng. 2015. Konsep Pendidikan Nilai. File.upi.edu/direktori/FPIPS/M-K-DU/diunduh pada 10 april 2015. Kusmayati, AM Hermien dan Suminto A. 2014. "Eksistensi Sastra Lisan Mamaca di Kabupaten Pamekasan, Madura" dalam Litera. Vol. 13 Nomor 1, April. Hlm. 182-190.

Manik, Ricky A. 2014. "Tradisi Lisan Kenduri Sko: Analisis Makna dan Fungsi” dalam Yos Adlis (Eds.) Antologi Hasil Penelitian Bahasa dan Sastra. Jambi: Kantor Bahasa Propinsi Jambi.

Mawadah, Ade Husnul. 2013. "Peran Cerita Rakyat Nusantara Dalam Pembentukan Karakter Cinta Budaya Indonesia" dalam Kundharu Saddhono et.al. Proceding Seminar Internasional. Surakarta: Universitas Sebelas Maret.

Miles, Matthew B. dan A. Michael Huberman. 2007. Analisis Data Kualitatif: Buku Sumber tentang Metode-metode Baru. Penerjemah Tjetjep Rohendi Rohidi. Jakarta: Universitas Indonesia.

Moleong, Lexy J. 2001. Metodologi Penelitian Kualitatif. Bandung: Remaja Rosdakarya.

Muhadjir, Noeng. 2002. Metodologi Penelitian Kualitatif. Yogyakarta: Rake Sarasin.

Mundardjito. 1986. "Hakikat Local Genius dan Hakikat Data Arkeologi" dalam Ayatrohaedi (Ed.) Kepribadian Budaya Bangsa (Local Genius). Jakarta: Pustaka Jaya.

Partowisastro, H. Koestoer.1983. Dinamika dalam Psikologi Pendidikan. Jakarta: Erlangga.

Purwadi. 2012. Folklor Jawa. Yogyakarta: Pura Pustaka.

Rahmanto, B. \& B. Kaswanti Purwo. 1999. Sastra Lihan: Pemahaman dan Interpretasi (Pilihan Karangan dalam Basis 1987-1995). Jakarta: Mega Media Abadi.

Salam, Dharma Setyawan. 2004. Otonomi Daerah: dalam Perspektif Lingkungan, Nilai, dan Sumber Daya. Jakarta: Djambatan.

Satori, Djam'an dan Aan Komariah. 2014. Metodologi Penelitian Kualitatif. Bandung: Alfabeta.

16 | Jurnal Kredo

Vol. 1 No. 1 Oktober 2017 